\title{
BUDGET PARTICIPATION AND BUDGETARY SLACK: THE MEDIATING EFFECT OF AUTONOMOUS BUDGET MOTIVATION
}

\author{
Novi Lailiyul Wafiroh ${ }^{1)^{*}}$, Fadlil Abdani $^{2}$, Fajar Nurdin $^{3)}$ \\ Department of Accounting, Faculty of Economics \\ Maulana Malik Ibrahim State Islamic University of Malang, Malang, Indonesia ${ }^{1,2,3)}$ \\ novilailiyulw@uin-malang.ac.id ${ }^{1)}$, fadlilabdani@uin-malang.ac.id ${ }^{2}$, nurdin.fajar@uin-malang.ac.id ${ }^{3)}$
}

\begin{abstract}
The purpose of our research is to provide empirical evidence of what and how participation in budgeting relates to the creation of budgetary slack conducted by managers through autonomous budget motivation. This research is expected to contribute to research and practice in the field of management accounting. Hypothetical testing is done empirically by collecting data through questionnaire dissemination surveys in various companies located in East Java. Data testing is performed with the help of the SmartPLS 3.0 app. The results of the data analysis showed that increased participation in budget preparation by managers from various departments led to a decrease in the creation of budgetary slack by managers. Nevertheless, the data test results were unable to prove that autonomous budget motivation was able to act as a mediation variable in the relationship between budget participation and budgetary slack. The results of the study indicate that only by actively participating in the budget preparation process, can directly reduce the tendency of employees to create budgetary slack without waiting for the high motivation of autonomous budgets that employees have first.
\end{abstract}

Keywords: Budget participation, Budgetary Slack, Autonomous Budget Motivation

*Corresponding author

Email: novilailiyulw@uin-malang.ac.id

DOI: https://doi.org/10.33369/j.akuntansi.10.3.287-300

\section{INTRODUCTION}

Siegel \& Marconi (1989) describes the budget as having a direct impact on individual behavior, especially for individuals who participated in the process of drafting a budget. This is what underlies the number of research accounting behavior related to budgeting that is still very relevant to be researched even today and experiencing rapid growth. The model that is often researched is the empirical testing of the influence of budget participation on budgetary slack behavior (Suhartini, Riadi, \& Sari, 2015). Budgeting research is still very relevant to be researched because budgeting is one of the most important things for planning, coordination, and organizational control. The manager requires an estimate of reliable future conditions to create effective budgeting (Nouri \& Parker, 1996). Budgeting is a detailed planning process for the use of resources for a certain period, both for acquisition, financial capital use, etc. Budgeting contains financial aspects and non-financial aspects of a planned project and operations since budgeting is a communication tool for top management with employees (Blocher, Stouth, \& Cokins, 2010).

A budgetary slack phenomenon is one of the topics that has gained much attention from researchers and is most examined in management accounting from year to year even the last few years (Chong, 2011 and Chen, Lu, Chang, \& Liu, 2016). Onsi (1973) presented his research results explaining that there was a negative relationship between the participation and the tendency of the manager to create slack, he added that the outcome of participation caused the manager to be less 
BUDGET PARTICIPATION AND BUDGETARY SLACK: THE MEDIATING EFFECT OF AUTONOMOUS BUDGET MOTIVATION

Novi Lailiyul Wafiroh, Fadlil Abdani, and Fajar Nurdin

interested in creating a slack. Not only does it show that participation plays an important role in reducing the budgetary slack, but Onsi (1973) also concluded participation promoted the attitude that the budget is not a game or accounting tool, so making the manager feel not under pressure to create slack. The results of Onsi Research (1973) are supported by the results of Merchant Research (1985) which suggests that the manager's tendency to create a slack is low when the manager actively participates in budgeting. The findings of Dunk (1993) also show that reduced slack is a result of participation. Pamungkas et.al., (2014), Tresnayani and Gayatri (2016), Permana, et.al., (2017) also found that budget participation harmed budgetary slack.

Unlike the previous research results (Dunk, 1993; Merchant, 1985; Onsi, 1973) stating that the budget participation negatively affects the budgetary slack, the study of budget participation in the budget preparation process conducted by Young (1985) succeeded in finding, that if the subordinates participated in the budget preparation process will cause budgetary slack, in which case the budget participation positively affects the budgetary slack. Nouri \& Parker (1996) shows the research results that budget participation affects budgetary slack. The latest Panelitian carried out by Baerdemaeker \& Bruggeman (2015) finds results if participation in strategy drafting has no direct association with the creation of a budgetary slack by the manager. Chong (2011) found if it was created a budgetary slack, in which the budget participation was influenced by subordinate belief to the employer. The lower the subordinate's belief in the employer in budget participation, the tendency to create budgetary slack will be higher. Unlike if the subordinates have a firm belief in the superiors, the tendency to create a budgetary slack in the activity of budget participation will be smaller. This is because the subordinates do not hesitate to provide relevant and more reliable information in the process of drafting the budgetary slack.

Pertiwi and Mahardhika (2019), Basyir (2017), Erina and Suartana (2016), Huseno (2017), Khasanah and Kristanti (2020), Rinaldi, et.al. (2020) found that budget participation had a positive effect on budget cuts. This means that budget cuts occur because the parties involved in budgeting provide biased information by reporting higher costs and lower revenues for budget targets to be reached. According to Basyir (2017), budget participation provides an opportunity for subordinates to do budgetary slack because subordinates are authorized in setting the contents of the budget and assessed based on the performance of the budget. According to Law 2310 No. 17 of 2003, the definition of performance-based budget is an approach in the preparation of a budget based on performance or achievement of work that wants to be achieved. The assessment sparked budgetary slack, as subordinates had more clear and accurate information that led to the asymmetry of information on the boss. The delivery of information from subordinates can not be conveyed properly to the superior. So, the more budgetary or subordinate the greater the opportunity to do budgetary slack due to information asymmetry.

In addition to the results of research conducted by Putra and Mintoyuwono (2019) and Bharata, et.al., (2020). They found that budget participation had no significant effect on budget cuts. This means that the high or low participation of the budget has no effect on the rise or fall of the budget or does not affect the budget. The results of the description that have been done indicate the inconsistency of previous research results. It indicates that other variables can affect the relationship between budget participation and budgetary slack. As a result of the statement Govindarajan (1986), that the difference in research results is influenced by variable contingencies so that it can be solved using a contingency approach, which is by adding other variables that may affect the relationship between budget participation and budgetary slack. An autonomous budget motivation is another variable of contingency that researchers use as mediation variables from budget participation and budgetary slack. The motivation of an autonomous budget is 
characterized by a feeling of freedom and underlying will. There is quite a lot of research in psychology regarding the motivation of autonomous budgets providing evidence of positive results. Unlike the controlled motivation characterized by a wide range of pressures, and many studies give a lot of negative results (Baerdemaeker \& Research, 2015).

According to Self-Determination Theory (SDT), the motivation of the autonomous budget can be cultivated through an environment that supports the needs and sustains three basic psychological needs inherent in all human beings, namely: 1) The need for Autonomy, 2) the need for competence, and 3) the need for interconnectedness (Baedemaeker et al., 2015). Employees who participated in the process of drafting the budget indirectly will fulfill all three basic needs of the employee's psychology and will give positive influence and increase the effectiveness in the process of drafting the budget to the achievement stage of the budget. This will motivate employees not to create budgetary slack in the process of drafting a budget. As a result of the research, Baerdemaeker \& Bruggeman (2015) Explain that budget participation does not directly affect the creation of budgetary slack, but budget participation does not directly influence the budgetary slack through the motivation of autonomous budget. According to Yuliastuti \& Prabowo (2015), high motivation has a significant negative effect on the relationship between the preparation of the budget with the budgetary slack, the higher the motivation in the individual involved in the process of drafting the budget can decrease the budgetary slack.

\section{THEORETICAL FRAMEWORKS AND HYPOTHESES}

\section{Agency theory}

Agency theory is used to identify the role of budget participation in creating dysfunctional behavior in the form of budget cuts. In this study, the agency's theory aims to explain the relationship between superiors and subordinates in the process of budgeting, especially when subordinates target budgets. The practice of budget cuts in the perspective of agency theory is influenced by the agency's conflict of interest with the principal that arises when each party strives to achieve or maintain the desired level of prosperity. The agent has more financial information than the principal, while the principal utilizes personal interests. If the agent participating in the budgeting process has specific information about local conditions, the agent can provide the information that is owned to help the interests of the company, but in this case, often the principal desire is not the same as the agent to create a conflict. The research results of Dunk (1993), Merchant (1985), and Onsi (1973) showed that negative budget participation in budgetary slack. That is, participation in budgeting is shown to reduce budgetary slack. This may be because subordinates will provide personal information about prospects, thereby enhancing the accuracy of the formulated budget. The positive communication between superiors and subordinates can reduce the motivation of subordinates to create a budgetary slack (Meredith \& Mantel, 2017). In contrast to the results of the study conducted by Young (1985) who found the reverse results. Young reveals that budget participation has a positive relationship to budgetary slack. The higher the level of participation in the budget preparation process, the possibility to create a budgetary slack will also be higher.

\section{Budget participation}

According to Mowen et al. (2014), The budget is a future financial plan that identifies the purpose and sleep that needs to be done so that the plan can be achieved. Participatory budgeting 
BUDGET PARTICIPATION AND BUDGETARY SLACK: THE MEDIATING EFFECT OF AUTONOMOUS BUDGET MOTIVATION

Novi Lailiyul Wafiroh, Fadlil Abdani, and Fajar Nurdin

is a budgeting system that allows managers to participate in and be responsible for the budget preparation process. The participatory budgeting system is one of the budgeting systems that can be used as a good communication tool for superiors and subordinates. Based on the explanation of the budget participation expressed by some researchers, it can be concluded that budget participation is a budget system that allows the lower-level manager or functional manager to participate in the process of making budget targets and be responsible for achieving the target budget.

\section{Budgetary Slack}

Govindarajan \& Anthony (2007) stated that the budgetary slack is the difference between the amount of the budget recommended or submitted by the subordinate with the amount of the optimal estimate of the company. The same is also reinforced by the statement of Kilfoyle \& Richardson (2010) which defines the budgetary slack as the difference between the budgeted resources and the resources needed to streamline the organizational achievement of the objectives. Other opinions are also expressed by Hobson et al. (2011) Explaining that the budgetary slack is created when subordinates shrink their skills or the ability of their business units in the budget they make.

\section{Autonomous budget motivation}

Based on self - determination theory, motivation will be differentiated into two sides. On the one hand, the motivation is divided into intrinsic motivation and extrinsic motivation. On the other hand, motivation is divided into Autonomous motivation (autonomous motivation), and controlled motivation (controlled motivation). Autonomous has the meaning of supporting one's actions at the highest level of reflection. Autonomous motivation is characterized by a feeling of being able to choose and thus behave in a self-determined manner. In other words, the person who acted considers the locus causality of this activity or himself as internal to him. Intrinsic motivation is an example of autonomous motivation. When people do activities because they feel attracted, they do the activity wholeheartedly. In contrast, controlled motivation involves action due to pressure, a feeling of being involved in the action. Autonomous motivation and controlled motivation (controlled motivation) are both intensive, and together they are contrary to the armory, involving lack of intent and motivation (Gagné \& Deci, 2005).

\section{Budget participation and budgetary slack}

The participation of the budget is birth by involving the entire party, both management up to the functional manager so as not to happen information monopoly. Because budget participation leads to positive communication because of an information exchange mechanism, the exchange of information and decision making together will reduce the bias of existing budget information, thereby reducing the likelihood of budgetary slack. Govindarajan \& Anthony (2007) show that the drafting of budget participation is an effective information exchange activity because managers in charge of the center of responsibility are most likely to have the best information about post income and costs. Atkinson et al. (2012) show that the method of participation offers additional benefits for management because the bottom manager discloses their personal information, disclosing data about how well they can do the work or allowing the introduction of new ideas that can help improve existing processes. Blocher et al. (2010) stated that participatory budgeting is increasing the employee's commitment to achieving a budget goal. 
Onsi (1973) presented his research results explaining that there was a negative relationship between the participation and the tendency of the manager to create slack, he added that the outcome of participation caused the manager to be less interested in creating a slack. The results of Onsi Research (1973) are supported by the results of Merchant Research (1985) which suggests that the manager's tendency to create a budgetary slack is low when the manager actively participates in budgeting. The findings of Dunk (1993) also show that reduced slack is a result of participation. Pamungkas et.al., (2014), Tresnayani and Gayatri (2016), Tegar, et.al., (2017) also found that budget participation harmed budgetary slack. Based on the explanation, the hypotheses proposed are:

$\mathrm{H}_{1}$ : Budget participation negatively affects budgetary slack

\section{Autonomous Budgets Motivation To Promote The Influence Of Budget Participation On Budgetary Slack}

Autonomous motivation (autonomous motivation) can form when three basic needs of psychology related to individual motivation have been fulfilled, namely the need for autonomy (autonomy), competence (competence), and bonding (relatedness). The functional manager allowed to participate in the budget drafting process will feel that their basic needs have been met, and this can foster an autonomous motivation to the manager in terms of budgets. Budget participation is believed to be able to provide a positive impact on employee motivation to increase the quantity and quality of production and cooperation between managers (Djalil \& Indriani, 2017). Baerdemaeker \& Bruggeman (2015) Displays the results of his research, which mentions that the increasing level of participation in strategic planning will increase the motivation of the autonomous budget motivation managers. The process of drafting a budget is one form of corporate strategy planning, and the participation of employees in the budget preparation process indicates the increased motivation of the employees ' autonomous budget.

Wong-On-Wing et al., (2010) describe a strong connection between autonomous motivation and positive work, such as performance, creativity, diligence, and initiative. Baerdemaeker \& Bruggeman (2015) also found negative influences from autonomous motivation to the creation of budgetary slack. This implies that managers who are autonomously driven (have autonomous motivation) will make greater efforts in finding solutions to achieve a target budget, and tend not to create a target budget that is more easily achieved (not creating a budgetary slack).

Budget participation can degrade the budgetary slack indirectly through the mediation role of the autonomous budget motivation (Baerdemaeker \& Research, 2015). When employees participate in a budget drafting process, this will motivate employees to increase their business in achieving a shared budget target that will lower the budgetary slack level. Positive motivation has a negative impact on the relationship between budget participation and budgetary slack. Indicating a high of the positive motivation of the manager in the budget, the lower the creation of the budgetary slack. Based on the explanation, the hypotheses proposed are:

$\mathrm{H}_{2}$ : The budget participation is a negative impact on the budgetary slack by the autonomous budgets motivation.

\section{RESEARCH METHODS}

This research is a type of exportation research aimed at explaining the influence of budget participation on budgetary slack by incorporating the effect of mediation of the motivation of 
BUDGET PARTICIPATION AND BUDGETARY SLACK: THE MEDIATING EFFECT OF AUTONOMOUS BUDGET MOTIVATION

Novi Lailiyul Wafiroh, Fadlil Abdani, and Fajar Nurdin

autonomous budgets with analytical units is individual. The individual is a functional manager, supervisor, head of a section, and also staff who are involved and in charge of drafting the budget on medium and large scale companies in East Java. Both companies are focused on the service sector, trade, and manufacturing.

The data type in this research is the primary data, which is directly obtained from the data source of the respondent. The data collection process is carried out in 2018. The data source or respondent in this study are employees involved in the process of drafting the budget up to the decision making budget target, both functional manager, supervisor, head of a section, as well as staff.

Variable budget participation is measured using a measurement instrument developed by Milani (1975) consisting of six indicators with a measurement scale using a Likert point scale of $1-7$. The variable budget is measured using a measurement instrument developed by Duke (1993) consisting of six indicators with a measurement scale using a Likert point scale of $1-7$ points. And the variable motivation of autonomous budgets is measured by assessing individual prestige against budget participation using measurement instruments developed by Wong-On-Wing (2010) with a total of seven question indicators measured using a Likert point scale of $1-7$.

The first step in conducting data analysis is to conduct a data quality test obtained, namely by conducting a validity test and data reliability test to know the appropriateness of each indicator of the question to be used as a tool to measure the research variable by using SPSS version 22. After the data quality test, the next step is to do model analysis and hypothesis testing. Data analysis techniques in this study used structural equation modeling-partial at least square with the help of SmartPLS software version 3.0. This study uses the SEM-PLS model because in this study the variables used are latent variables (unobservable variables), i.e. autonomous budget motivation variables as mediation variables, budget participation variables as independent variables, and budget twilight variables as dependent variables, all of which are constructed using indicators as measurements.

\section{RESULTS AND DISCUSSION}

Based on the analysis results, the description can be known from this table about the position of respondents at the time of completing the questionnaire

Table 1. Descriptive Statistic

\begin{tabular}{|c|c|c|c|c|}
\hline Position & $\begin{array}{l}\text { Length of } \\
\text { Work }\end{array}$ & Participation & Involvement & $\begin{array}{c}\text { Budget } \\
\text { Determinant }\end{array}$ \\
\hline $\begin{array}{l}\text { Vice Precident } \\
3(4,1 \%)\end{array}$ & $\begin{array}{l}<1 \text { year } \\
4(5,4 \%)\end{array}$ & $\begin{array}{l}\text { Do not participate } \\
0(0 \%)\end{array}$ & $\begin{array}{l}\text { Not Involved } \\
16(21,6 \%)\end{array}$ & $\begin{array}{l}\text { Boss } \\
64(86,5 \%) \\
\end{array}$ \\
\hline $\begin{array}{l}\text { CEO } \\
1(1,4 \%) \\
\end{array}$ & $\begin{array}{l}1-3 \text { years old } \\
31(41,9 \%)\end{array}$ & $\begin{array}{l}\text { Participate } \\
74(100 \%)\end{array}$ & $\begin{array}{l}\text { Involved } \\
58(78,4 \%) \\
\end{array}$ & $\begin{array}{l}\text { My self } \\
10(13,5 \%)\end{array}$ \\
\hline $\begin{array}{l}\text { Functional Manager } \\
10(13,5 \%)\end{array}$ & $\begin{array}{l}4-6 \text { years old } \\
15(20,3 \%)\end{array}$ & $-\quad-$ & $-\quad-$ & $-\quad-$ \\
\hline $\begin{array}{l}\text { Supervisor } \\
10(13,5 \%)\end{array}$ & $\begin{array}{l}7-9 \text { years old } \\
3(4,1 \%)\end{array}$ & - & - & - \\
\hline $\begin{array}{l}\text { Staff } \\
41(55,4 \%)\end{array}$ & $\begin{array}{l}\geq 10 \text { years old } \\
21(21 \%)\end{array}$ & - & - & - \\
\hline Others $9(12,2 \%)$ & $\begin{array}{ll}- & -\end{array}$ & - & - & - \\
\hline $\begin{array}{c}\text { Total } \\
74(100 \%)\end{array}$ & $\begin{array}{c}\text { Total } \\
74(100 \%)\end{array}$ & $\begin{array}{c}\text { Total } \\
74(100 \%)\end{array}$ & $\begin{array}{c}\text { Total } \\
74(100 \%)\end{array}$ & $\begin{array}{c}\text { Total } \\
74(100 \%)\end{array}$ \\
\hline
\end{tabular}


Respondents who served as Vice president were 3 people $(3.7 \%)$, the respondent who served as the CEO was 1 person (1.2\%), the respondent who served as functional manager there were 10 people $(13.5 \%)$, the respondent who served as supervisor of 10 people $(13.65 \%)$, the respondent who served as employee staff there were 41 people $(55.4 \%)$, and the respondent who served as other staff there were 9 people $(12.2 \%)$. For the old category of working 21 respondents (28.4\%) has been working for the company for more than ten years, 3 (4.1\%) Respondents have been working for the company for 7-9 years, 15 (20.3\%) Respondents have been working for the company for 4-6 years, 31 (41.9\%) Respondents have been working for the company for 1-3 years, and $4(5.4 \%)$ Respondents have been working for the company for less than one year. Based on the category of participation in the budget preparation process can be known that the entire respondent participated in the process of drafting the budget, so it is expected that the data to be processed can then be valid and reliable. For the category of involvement in budget preparation based on table 1, it is known that from 74 respondents, several 58 respondents $(78.4 \%)$ Involved in the budget preparation process, while several 16 respondents $(21.6 \%)$ Not involved in the budget drafting process. And lastly is for the category of authorities determining the budget can be noted that the majority of respondents stated that determining the budget is the employer of 64 respondents (86.4\%), while the remaining ten respondents (13.6\%) Answer them that determines the budget amount.

\section{Validity Test and Reliability Test}

Discriminant validity is measured by comparing the square root value of each construct Variance Extracted (AVE) square root with the correlation between other constructs in the model. The AVE value must be greater than 0.30 or have a $\mathrm{p}$-value smaller than the significance level (0.05). The results of the discriminant validity measurement in this study can be seen in this table:

Tabel 2. Discriminant validity measurement results

\begin{tabular}{c|c}
\hline Variable & Original Sample $(\mathrm{O})$ \\
\hline Budgetary Slack & 0,870 \\
\hline Budget Participation & 0,823 \\
\hline Autonomous Budget Motivation & 0,804 \\
\hline
\end{tabular}

Based on that table, all variables have a discriminant validity value above 0.50 . From these results, it can be concluded that all variables are valid and can provide confidence. Once the variable has been declared valid, the realization test of all variables used in this study is carried out. Variable reliability is tested using composite reliability techniques. To determine whether or not a measuring instrument is performed through a reliability coefficient. The coefficient of reliability should be greater than 0.70 . The results of the composite reliability measurement can be seen in the table below.

Tabel 3. Composite Reliability measurement results

\begin{tabular}{c|c}
\hline Variable & Original Sample $(\mathrm{O})$ \\
\hline Budgetary Slack & 0,862 \\
\hline Budget Participation & 0,918 \\
\hline Autonomous Budget Motivation & 0,940 \\
\hline
\end{tabular}


BUDGET PARTICIPATION AND BUDGETARY SLACK: THE MEDIATING EFFECT OF AUTONOMOUS BUDGET MOTIVATION

Novi Lailiyul Wafiroh, Fadlil Abdani, and Fajar Nurdin

Based on that table, all variables have a composite reliability value greater than 0.70 . From these results, it can be concluded that all the variables in the study are reliable and reliable for use in further analysis tests.

\section{Confirmatory Factor Analysis}

The measuring model or outer model is evaluated using the validity and linear validity of the indicator and the composite reliability for the indicators block, as for structural models or inner models evaluated by looking at the value of R2 for the dependent latent construct using the size of Stone-Geisser Q Square-Test. Because this research uses a multidimensional construct, the secondorder analysis is used. The following analysis results are obtained using the analysis factor second order.

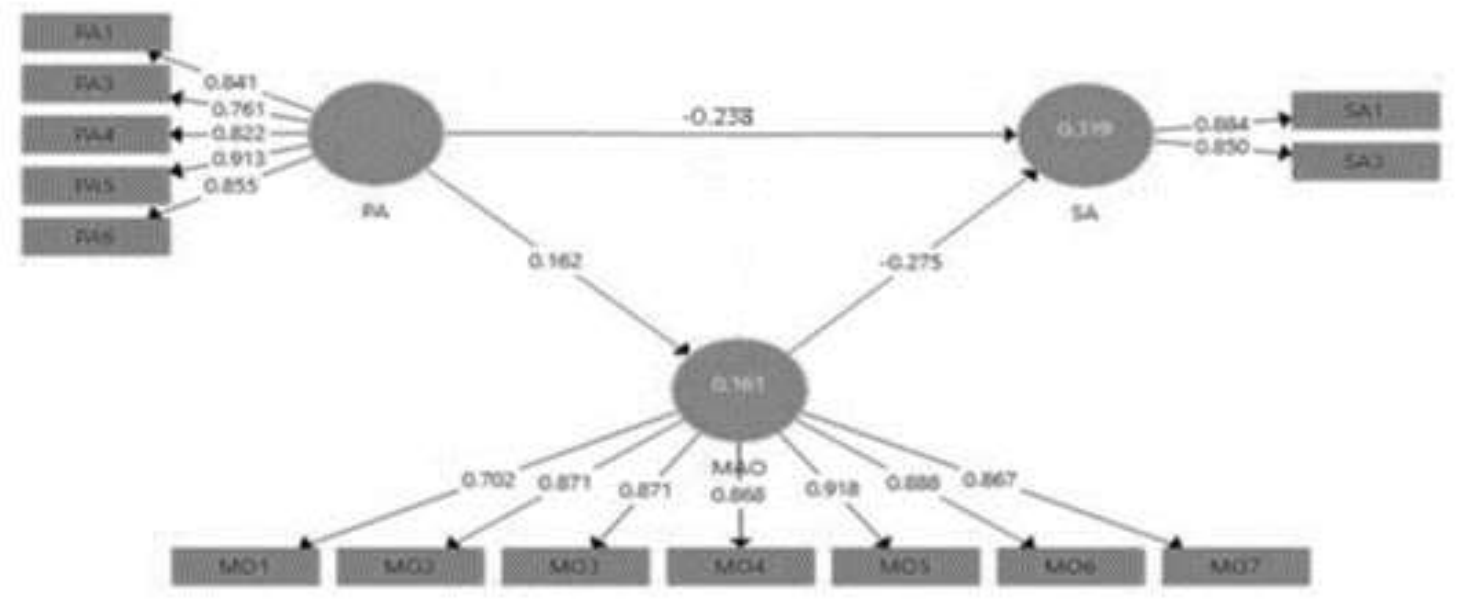

Figure 1. Conceptual Model Confirmatori Final Stage indicator

Based on the information already presented in the table above, the following are the results of the analysis done to test the outer model: The autonomous budget motivation variable indicates the overall indicator has an outer loading factor value above 0.6 , with a T-Statistic value greater than 1.99. MO1 with an outer loading factor of 0702 and a T-Statistic value of 5,466, MO2 with an outer loading factor of 0871 and a T-Statistic value of 6,430, MO3 with an outer loading factor of 0871 and a T-Statistic value of 4,835, MO4 with an outer loading factor of 0868 and a T-Statistic value of 4,729, MO5 with an outer loading factor of 0918 and a T-Statistic value of 5,187, MO6 with an outer loading factor of 0888 and a T-Statistic value of 4,779, and MO7 with an outer loading factor of 0867 and a T-Statistic value of 5,635.

The budget participation variable shows the overall indicator has an outer loading factor value above 0.7 , with a T-Statistic value greater than 1.99 . PA1 with an outer loading factor of 0841 and a T-Statistic value of 7,464, PA3 with an outer loading factor of 0761 and a T-Statistic value of 6,047, PA4 with an outer loading factor of 0822 and a T-Statistic value of 6,746, PA5 with an outer loading factor of 0913 and a T-Statistic value of 11,032, and PA6 with an outer loading factor of 0855 and a T-Statistic value of 9,230.

The budgetary slack variable based on the results of the analysis in the table above indicates that the SA1 and SA3 indicators meet the criteria for having an outer loading factor greater than 0.7 with a T-Statistic value greater than 1.99 , which is SA1 with an outer loading factor of 0884 
and a T-Statistic value of 11,908 and SA3 with an outer loading factor of 0850 and a T-statistic value of Based on the results above, it can be concluded that the measurements for the entire variable of this study meet convergent validity.

Table 4. Evaluation of Confirmatory Conceptual Model Final Stage Indicators

\begin{tabular}{|c|c|c|c|c|c|}
\hline $\begin{array}{l}\text { Measurement } \\
\text { Model }\end{array}$ & \multicolumn{3}{|c|}{ Score } & $\begin{array}{l}\text { Critical } \\
\text { Value }\end{array}$ & $\begin{array}{c}\text { Model } \\
\text { Evaluation }\end{array}$ \\
\hline \multicolumn{6}{|c|}{ Outer Model } \\
\hline \multirow{15}{*}{$\begin{array}{l}\text { Reliability } \\
\text { indicator }\end{array}$} & Indicator & Loading Factor & $T$-Statistics $S$ & & \\
\hline & MO1 & 0702 & 5.466 & \multirow{7}{*}{$>0.6$} & \multirow{7}{*}{ Good } \\
\hline & $\mathrm{MO} 2$ & 0871 & 6,430 & & \\
\hline & MO3 & 0871 & 4,835 & & \\
\hline & MO4 & 0868 & 4,729 & & \\
\hline & MO5 & 0.918 & 5,187 & & \\
\hline & MO6 & 0888 & 4,779 & & \\
\hline & MO7 & 0867 & 5635 & & \\
\hline & PA1 & 0841 & 7,464 & \multirow{5}{*}{$>0.6$} & \multirow{5}{*}{ Good } \\
\hline & PA3 & 0.761 & 6,047 & & \\
\hline & PA4 & 0822 & 6,746 & & \\
\hline & PA5 & 0.913 & 11,032 & & \\
\hline & PA6 & 0.855 & 9,230 & & \\
\hline & SA1 & 0.884 & 11,908 & \multirow{2}{*}{$>0.6$} & \multirow{2}{*}{ Good } \\
\hline & SA3 & 0850 & 6.215 & & \\
\hline \multirow{4}{*}{$\begin{array}{c}\text { Internal } \\
\text { Consistency } \\
\text { Reliability }\end{array}$} & Variable & \multicolumn{2}{|c|}{ Composite reliability } & & \\
\hline & MAO & & & & \\
\hline & $\mathrm{PA}$ & & & $>0.7$ & Good \\
\hline & SA & & & & \\
\hline \multirow{4}{*}{$\begin{array}{l}\text { Convergent } \\
\text { Validity }\end{array}$} & Variable & \multicolumn{2}{|c|}{ Average variance extracted (AVE) } & \multirow{4}{*}{$>0.50$} & \multirow{4}{*}{ Good } \\
\hline & MAO & & & & \\
\hline & $\mathrm{PA}$ & & & & \\
\hline & SA & & & & \\
\hline \multirow{5}{*}{$\begin{array}{l}\text { Discriminant } \\
\text { validity }\end{array}$} & & AVE Root Squ & Correlation Bet & en Latent & \\
\hline & Variable & \begin{tabular}{l|l} 
MAO & P \\
\end{tabular} & \begin{tabular}{|c|c|} 
SA & \\
\end{tabular} & & \\
\hline & MAO & 0857 & & Higher & \\
\hline & PA & 0.188 & & Higher & Good \\
\hline & SA & -0.430 & 0867 & Higher & \\
\hline & & Inner 1 & & & \\
\hline & Variable & Rule & & & \\
\hline R-Square & MAO & & & $>0.2$ & Not good \\
\hline & $\mathrm{SA}$ & & & & \\
\hline Adi P Square & MAO & & & $>025$ & Not oood \\
\hline Adj. R-Square & $\mathrm{SA}$ & & & $\geq 0.25$ & Not good \\
\hline & MAO & & & & \\
\hline Full Coll VIF & PA & & & $\leq 3.3$ & Good \\
\hline & SA & & & & \\
\hline O_Sauare & MAO & & & $>0$ & Releyant \\
\hline Q-square & SA & & & $>0$ & Kelevant \\
\hline
\end{tabular}

Source: Processed data 
BUDGET PARTICIPATION AND BUDGETARY SLACK: THE MEDIATING EFFECT OF AUTONOMOUS BUDGET MOTIVATION

Novi Lailiyul Wafiroh, Fadlil Abdani, and Fajar Nurdin

\section{Average Variance Extracted (AVE)}

Based on the table of analysis results Confirmation of measurement instrument above can be known that the AVE quadratic root value of the autonomous budget motivation variable (0368), Budget participation variables (0073) and budgetary slack (-0420) variables. The value of the AVE quadratic roots of the autonomic budget (0857) variable is higher than the correlation value of the budget participation variables (0188) and the value of the variable correlation budgetary slack (0430). The value of the quadratic root of the AVE variable participation budget (0840) is higher than the variable correlation value of the budgetary slack (-0312), and the value of the quadratic root of the AVE variable participation budget is 0867. Based on the resulting value can be concluded that each of the research construction has a good value linear validity.

\section{Composite Reliability}

Based on the table above, it can be known that the result of composite reliability is satisfactory because the value above 0.7 , so it can be concluded that the entire block of items is indeed a gauge of its construction.

\section{Hypothesis Testing}

Hypothesis testing results by comparing the T-count value to the T-table value. If the Tcount value is greater than T-table, then the relationship between variables is said to be significant and can be analyzed further. With the amount of data 74, the T-table value $(\alpha=5 \%)$ of 1.99 and T-table value $(\alpha=10 \%)$ of 1.67 . Hypothesis testing results are presented in table below:

Table 5. Hypothesis Testing Results

\begin{tabular}{|c|c|c|c|c|c|c|c|c|}
\hline $\mathbf{H}$ & & & Effect & & & $\begin{array}{l}\text { Koef } \\
\text { Path }\end{array}$ & $\begin{array}{c}T \\
\text { Count }\end{array}$ & Description \\
\hline $\mathrm{H} 1$ & $\begin{array}{c}\text { Budget } \\
\text { Participation (PA) }\end{array}$ & $\rightarrow$ & $\begin{array}{c}\text { Budgetary Slack } \\
\text { (SA) }\end{array}$ & & & -0.237 & 2.761 & Significant \\
\hline $\mathrm{H} 2$ & $\begin{array}{c}\text { Budget } \\
\text { Participation (PA) }\end{array}$ & $\rightarrow$ & $\begin{array}{c}\text { Autonomous Budget } \\
\text { Motivation (MAO) }\end{array}$ & $\rightarrow$ & $\begin{array}{l}\text { Budgetary } \\
\text { Slack (SA) }\end{array}$ & -0.228 & 1.217 & $\begin{array}{c}\text { Not } \\
\text { Significant }\end{array}$ \\
\hline
\end{tabular}

* Significant at a level of 5\%, T-table value at level 5\% $=1.99$

According to table above, it can be noted that: Budget participation (PA) has a significant negative influence on the budgetary slack (SA) with a CR value of T-count > T-table $(2,219>$ 1,996) and a coefficient of path of-0298, this coefficient indicates that with the higher level of participation in budget preparation process can lower the tendency to create budgetary slack Budget participation has a negative and insignificant influence on a budget (SA), through autonomous budget motivation (MAO) mediation with a CR value of T-count < T-table $(1,217<$ $1,668)$ and a coefficient of path of-0228, this coefficient indicates that with the higher level of budget participation can lower the trend of the creation of budgetary slack, because of the increasing the motivation of the autonomous

\section{DISCUSSION}

The Influence Of Budget Participation On Budgetary slack

Hypothesis 1 states that negative budget participation affects budgetary slack. The results of the study using statistical tests showed a significant negative budget participation variable on the budgetary slack, resulting in hypotheses 1 acceptable $\left(\mathrm{H}_{1}\right.$ accepted). The negative influence of budget participation on budgetary slack means the higher the participation rate in the process of 
drafting the company budget, the lower the budgetary slack level is created. Budget participation should be done actively by all layers of the company members, starting from the very bottom staff who actually know the real condition of the company's operational activities because they are directly plunging in it, supervisor, head of a section, functional manager, budget board to top management.

The high level of involvement of all employees in the budget preparation process will encourage every employee to express and give their opinion either willingly or when asked by the employer to give an opinion. This is what will make the employees feel very appreciated by the company because it is given the opportunity to participate and contribute to developing the company's final budget. By instilling feelings of belonging and upholding togetherness in expressing an opinion to formulate a company's budget, it will make employees more likely to express all the information that belongs to the budget in accordance with the capabilities. The more information about the budget value that approaches the standard and the normal capacity that should be achieved, the lower the creation of more and fewer budget differences. The creation of budgetary slack in the budget preparation process can also be suppressed because the absorption of all information relating to the budget value can occur well.

Agency problems that often arise in the process of budgeting are due to the inability of a functional manager to absorb information obtained from employee staff related to how much real budget is needed so that the budgeted value really approaches even according to operational needs occurring within the company. This is called the information gap, which is the gap arising from the person planning the budget (functional manager, budget board and top manager) with the person executing (employee staff).

Atkinson et al. (2012) show that the method of participation offers additional benefits for management because the bottom manager discloses their personal information, disclosing data about how well they can do the work or allowing the introduction of new ideas that can help improve existing processes. Blocher et al. (2010) stated that participatory budgeting is increasing the employee's commitment to achieving a budget goal. Onsi (1973) presented his research results explaining that there was a negative relationship between the participation and the tendency of the manager to create a slack, he added that the outcome of participation caused the manager to be less interested in creating a slack. The results of Onsi Research (1973) are supported by the results of the Merchant Research (1985) which suggests that the manager's tendency to create a slack is low when the manager actively participates in budgeting. The findings of Dunk (1993) also show that reduced slack is a result of participation.

The influence of budget participation on budgetary slack through autonomous budget motivation Hypothesis 2 states that negative budget participation affects the budgetary slack through the motivation of autonomous budgets. The results of the study using statistical tests showed negative but insignificant budget participation variables through autonomous budget motivation, so hypotheses 2 were not accepted $\left(\mathrm{H}_{2}\right.$ not accepted). The results indicated that only by actively participating in the budget preparation process can directly reduce the tendency of employees to create a budgetary slack without waiting for the high motivation of the autonomous budget that employees have in advance. It signifies that the role of budget participation is very high in the context of eliminating the tendency to create budgetary slack in the process of budgeting.

The opportunity to engage and participate in the preparation of budgets given by the company to employees will be used as a means for employees to be able to set higher objectives 
and is ultimately utilized as a means to evaluate the objectives that have been established. In addition, the implementation of budget participation is also used as a means of information exchange. Employees involved in budget participation provide the information they have in relation to the establishment of a budget amount to the employer, and the employer allows the utilization of information obtained from subordinates for better decision-making regarding the determination of the amount of budget required for the company.

Autonomous motivation (autonomous motivation) can form when three basic needs of psychology related to individual motivation have been fulfilled, namely the need for autonomy (autonomy), competence (competence), and bonding (relatedness). The functional manager given the opportunity to participate in the budget drafting process will feel that their basic needs have been met, and this can foster an autonomous motivation to the manager in terms of budgets. Functional managers will be motivated to accept and run a budget that has been drafted and shared in accordance with the choice without feeling depressed or forced with a predetermined budget.

When the functional manager feels that the three basic needs of their psychology are fulfilled through the process of drafting the budget target that they participate in, it can directly influence and increase the autonomous motivation that the functional manager has. This will increase the confidence of the manager functional in determining the option to accept and execute the operational activities of the company as it should so that the target budget that has been set together can be achieved well. The increased autonomous motivation of functional managers against the budget will be able to improve the positive performance of functional managers (Wong-On-Wing et al., 2010), which means that functional managers will deliver their best performance by not creating a slack in the value they propose as the basis of determining their accountability centre budget targets. The results of this study did not support the results of research conducted by Baerdemaeker \& Bruggeman (2015) stating that budget participation can degrade the budgetary slack indirectly through the mediation role of the autonomous budget motivation.

\section{CONCLUSION}

This research examines the role of autonomous budget motivation mediation in the influence of budget participation on budgetary slack. The following is the conclusion of the results of the statistical data analysis that has been done. Budget participation variables proved negative and significant to the budgetary slack. This means that the higher the budget participation rates in the process of budgeting, the lower the tendency in creating a budgetary slack. This results in line with the results of empirical research conducted by Onsi (1973), Merchant (1985) and Dunk (1993). Budget participation variables proved negative but not significant to budgetary slack through the mediation of the autonomous budget motivation variables. The results indicated that only by actively participating in the budget preparation process can directly reduce the tendency of employees to create a budgetary slack without waiting for the high motivation of the autonomous budget that employees have in advance. It signifies that the role of budget participation is very high in the context of eliminating the tendency to create budgetary slack in the process of budgeting. 


\section{BIBLIOGRAPHY}

Anthony, R., \& Govindarajan, V. (2007). Management control systems (Twelfth Ed). McGrawHill International Edition.

Atkinson, A., Kaplan, R., Matsumura, E., \& Young, S. (2012). Management Accounting: Information for Decision-making and Strategy Execution. Essex. In Pearson (((6th ed.)).

Baerdemaeker, J. De, \& Research, W. B. (2015). The impact of participation in strategic planning on managers' creation of budgetary slack: The mediating role of autonomous motivation and affective organisational. Management Accounting Research, 29, 1-12.

Basyir, A. A. (2017). Pengaruh Partisipasi Anggaran, Informasi Asimetri, dan Kapasitas Individu Terhadap Budgetary Slack Pada SKPD Pemerintah Kota Samarinda. Akuntabel: Jurnal Ekonomi Dan Keuangan, 13(2), 82-102.

Blocher, E. J., Stouth, D. E., \& Cokins, G. (2010). Cost Management a strategic emphasis Fifth Edition. In McGraw-Hill (Fifth Edit).

Chen, D., Lu, C., Chang, A., \& Liu, H. (2016). The relationships among budgetary slack, customers' relationship quality and organizational performance. 5th IIAI International Congress on Advanced Applied Informatics.

Chong, V. K. (2011). Article in Advances in Management Accounting. Emerald Group Publishing Limited, 19, 55-73. https://doi.org/10.1108/S1474-7871(2011)0000019009

Djalil, M. A., \& Indriani, M. (2017). The Influence of Organizational Commitment and Motivation in the Relationship between Budget Participation and Managerial Performance (Empirical Study on Provincial Government Agencies ( SKPA) of Aceh Province, Indonesia). BRAND. Broad Research in Accounting, Negotiation, and Distribution, 8, 12-24.

Duke, D. J., \& Harrison, M. D. (1993). Abstract Interaction Objects. Computer Graphics Forum, 12(3), 25-36. https://doi.org/10.1111/1467-8659.1230025

Dunk, A. (1993). The effect of budget emphasis and information asymmetry on the relation between budgetary participation and slack. The Accounting Review, (68) 02, 400-410.

Erina, N. P. D., \& Suartana, W. (2016). Pengaruh partisipasi penganggaran, penekanan anggaran, kapasitas individu, dan kejelasan sasaran anggaran pada senjangan anggaran. In E-Jurnal Akuntansi (15).

Gagné, M., \& Deci, E. L. (2005). Self-determination theory and work motivation. Journal of Organizational Behavior, (26)4, 331-362. https://doi.org/10.1002/job.322

Govindarajan, V. (1986). Impact of Participation in the Budgetary Process on Managerial Attitudes and Performance: Universalistic and Contigency Perpectives. Decision Sciences, 17(4), 496516. https://doi.org/10.1111/j.1540-5915.1986.tb00240.x

Hobson, J. L., Mellon, M. J., \& Stevens, D. E. (2011). Determinants of Moral Judgments Regarding Budgetary Slack:An Experimental Examination of Pay Scheme and Personal Values. Behavioral Research In Accounting. Behavioral Research in Accounting, (23)1, 87107. https://doi.org/10.2308/bria.2011.23.1.87

Huseno, T. (2017). Pengaruh Partisipasi Anggaran, Komitmen Organisasi dan Ketidakpastian Lingkungan Terhadap Senjangan Anggaran Pemerintah Provinsi Sumatera Barat. Jurnal Teori Dan Riset Administrasi Publik, (1)1.

Khasanah, S. N., \& Kristanti, I. N. (2020). Pengaruh Partisipasi Anggaran, Kapasitas Individu, Self Esteem dan Kejelasan Sasaran Anggaran Terhadap Senjangan Anggaran Desa di Kecamatan Petanahan. Jurnal Ilmiah Mahasiswa Manajemen, Bisnis Dan Akuntansi. 
BUDGET PARTICIPATION AND BUDGETARY SLACK: THE MEDIATING EFFECT OF AUTONOMOUS BUDGET MOTIVATION

Novi Lailiyul Wafiroh, Fadlil Abdani, and Fajar Nurdin

Kilfoyle, E., \& Richardson, A. J. (2010). Agency and structure in budgeting: Thesis, antithesis and synthesis. Critical Perspectives on Accounting, 22, 183-199. https://doi.org/10.1016/j.cpa.2010.06.013

Merchant, K. (1985). Budgeting and the propensity to create budgetary slack. Accounting, Organizations and Society, (10) 02, 201-210.

Meredith, J. R., \& Mantel, S. J. (2017). Project management. A managerial approach.

Milani, K. (1975). The relationship of participation in budget-setting to industrial supervisor performance and attitudes: a field study. The Accounting Review.

Mowen, M., Hansen, D., \& Heitger, D. (2014). Cornerstones of managerial accounting (Fifth ed.). South-Western Cengage Learning.

Nouri, H., \& Parker, R. (1996). The effect of organizational commitment on the relation between budgetary participation and budgetary slack. Behavioral Research in Accounting, 8, 74-90.

Onsi, M. (1973). Factor analysis of behavioral variables affecting budgetary slack. The Accounting Review, (48)03.

Pamungkas, I. M. B. W., Adiputra, I. M. P., \& Sulindawati, N. L. G. E. (2014). Pengaruh partisipasi anggaran, informasi asimetri, budaya organisasi, kompleksitas tugas, reputasi, etika dan self esteem terhadap budgetary slack (studi pada. Jurnal Ilmiah Mahasiswa Akuntansi, (2)1.

Pertiwi, D., \& Mahardhika, A. (2019). Anteseden Senjangan Anggaran Desa Di Kabupaten Kebumen. Muhammadiyah Riau Accounting and Business Journal, (1)1, 39-45.

Putra, I. G. E. D., \& Mintoyuwono, D. (2019). Pengaruh Partisipasi Anggaran, Penekanan Anggaran, dan Komitmen Organisasi Terhadap Senjangan Anggaran Pada Suku Dinas Pemerintahan Di DKI Jakarta. In EQUITY (20).

Rinaldi, Agustin, H., \& Sari, V. F. (2020). Pengaruh Partisipasi Anggaran Terhadap Kesenjangan Anggaran Dengan Komitmen Organisasi Sebagai Variabel Pemoderasi. Jurnal Eksplorasi Akuntansi, 2(1), 2299-2313.

Siegel, G., \& Marconi, H. (1989). Behavioral Accounting South-Western Publishing Co. Cincinati.

Suhartini, D., Riadi, E., \& Sari, R. (2015). Model Budgetary Slack dan Kinerja Manajerial: Berprespektif Gender. Jurnal Manajemen.

Tegar, O., Eliada Herwiyanti, P., \& Mustika, W. (2017). Pengaruh Partisipasi Anggaran, Asimetri Informasi, Tekanan Anggaran Dan Komitmen Organisasi Terhadap Senjangan Anggaran Di Pemerintah Kabupaten. Jurnal Organisasi Dan Manajemen, (13)2.

Tresnayani, L. G. A., \& Gayatri. (2016). Pengaruh Partisipasi Anggaran, Asimetri Informasi, Kapasitas Individu, dan Kejelasan Sasaran Anggaran Terhadap Potensi Terjadinya Budgetary Slack. Jurnal Akuntansi Universitas Udayana, (6)2.

Wong-On-Wing, B., Guo, L., \& Lui, G. (2010). Intrinsic and extrinsic motivation and participation in budgeting: Antecedents and consequences. Behavioral Research in Accounting, (22)2, 133-153. https://doi.org/10.2308/bria.2010.22.2.133

Young, S. M. (1985). Participative Budgeting: The Effects of Risk Aversion and Asymmetric Information on Budgetary Slack. In Journal of Accounting Research (23).

Yuliastuti, Y., \& Prabowo, M. A. (2015). Pengaruh Partisipasi Penyusunan Anggaran Pendapatan Dan Belanja Sekolah (Apbs) Terhadap Budgetary Slack Dengan Motivasi Dan Komitmen Organisasi. Jurnal Paradigma, (12) 02, 92-113. 